\title{
A species-level comparison of occurrence patterns in carabids along an urbanisation gradient
}

\author{
Tibor Magura $^{\mathrm{a}, *}$, Béla Tóthmérész ${ }^{\mathrm{b}}$, Tivadar Molnár ${ }^{\mathrm{c}}$ \\ ${ }^{a}$ Hortobágy National Park Directorate, H-4002 Debrecen, P.O. Box 216, Hungary \\ ${ }^{\mathrm{b}}$ Ecological Institute, University of Debrecen, H-4010 Debrecen, P.O. Box 71, Hungary \\ ${ }^{\mathrm{c}}$ Department of Zoology, University of Debrecen, H-4010 Debrecen, P.O. Box 3, Hungary \\ Received 20 April 2007; received in revised form 28 January 2008; accepted 30 January 2008
}

\begin{abstract}
The activity-density pattern of frequent carabid species was studied using pitfall traps in forest patches along an urbanisation gradient defined in terms of the ratio of the built-up area to the natural habitat. We predicted that the activity-density of the forest specialist carabid species should decrease from rural sites to the more altered urban ones. We also predicted, that there is no unique pattern for the generalist species, because the activity-density pattern is controlled by their autecological characteristics in a complex interaction with the environmental variables, and urbanisation/disturbance level. Moreover, we identified the environmental factors responsible for the observed variation in carabid activity-density.

As predicted, the activity-density of two forest specialist species (Carabus convexus, Pterostichus oblongopunctatus) decreased significantly from rural sites to urban ones. The activity-density of the generalist species, Amara convexior, was higher in the heavily disturbed urban sites. The generalist species, Ophonus nitidulus, was significantly more abundant in the rural sites. The other five frequent generalist species (Notiophilus rufipes, Pterostichus melanarius, Harpalus luteicornis, Pterostichus niger, Stomis pumicatus) showed no significant changes in activity-density along the gradient. The two open-habitat species (Anisodactylus nemorivagus, Bembidion lampros) also showed no significant changes in activity-density along the gradient. Canonical correspondence analysis highlighted that the variation in the activity-density of the studied species was related to the following environmental factors: ground temperature, air temperature, relative humidity, leaf-litter cover, cover of decaying wood material, herbs, shrubs, and to the amount of prey items.
\end{abstract}

(C) 2008 Published by Elsevier B.V.

Keywords: Activity-density; Forest specialist carabids; Generalist species; Open-habitat species; Urbanisation

\section{Introduction}

Today, most people are city dwellers and roughly $80 \%$ of the human population of developed countries lives in and around cities (United Nations, 2004). Increasing urbanisation changes a large number of factors, including temperature (Hawkins et al., 2004), utilisable carbon (Pouyat et al., 2002) and nitrogen levels (Zhu and Carreiro, 2004), leaf-litter decomposition rates (McDonnell et al., 1997), soil properties (Pouyat et al., 1995), trampling intensity (Grandchamp et al., 2000), numbers of exotic, invasive and generalist floral and faunal species (Weifeng et al., 2006; Godefroid and Koedam, 2003), habitat loss and fragmentation (Gibbs and Stanton, 2001).

\footnotetext{
* Corresponding author. Tel.: +36 52529 920; fax: +36 52529940 .

E-mail address: magura@www.hnp.hu (T. Magura).
}

In 1998, an international initiative, the Globenet programme (Global Network for Monitoring Landscape Change), commenced to assess and compare the impact of urbanisation (Niemelä and Kotze, 2000; Niemelä et al., 2000). As the effects of urbanisation on biodiversity can be explored most effectively through investigations along rural-to-urban gradients (McDonnell et al., 1997), the Globenet programme also employed this gradient approach. The Globenet programme used a common, standardised methodology (pitfall trapping) and a common invertebrate taxon (carabid beetles; Coleoptera: Carabidae) to analyse how invertebrate assemblages vary across the different parts of the world along the rural-urban gradients (Niemelä et al., 2000). Carabid beetles were selected as the focal taxon because they are fairly easy to collect and preserve, diverse and abundant, taxonomically and ecologically well known and their relatively short generation times mean that they may respond quickly to anthropogenic effects (Lövei and 
$54 \quad$ Sunderland, 1996). All these features of carabid beetles make ${ }_{55}$ them a reliable monitoring group (McIntyre, 2000; Rainio and $56 \quad$ Niemelä, 2003).

Globenet programme results concerning carabid beetles have been published from Belgium, Bulgaria, Canada, Denmark, England, Finland, Hungary and Japan (Alaruikka et al., 2002; Niemelä et al., 2002; Ishitani et al., 2003; Venn et al., 2003; Magura et al., 2004b, 2005b; Elek and Lövei, 2005, 2007; Gaublomme et al., 2005; Tóthmérész and Magura, 2005; Sadler et al., 2006). Up to now, these studies have analysed how species richness and activity-density of carabid assemblages vary along the rural-urban gradients, but neglected to investigate the occurrence pattern of individual carabid species across the gradients. However, analysing variations in activity-density at the species level along the rural-urban gradient is extremely important, because urbanisation first affects the population level, and changes at population levels generate alteration afterwards on the community level.

The aim of this study was to investigate the effects of urbanisation on the occurrence pattern of carabid beetles along a rural-urban gradient and to identify environmental factors responsible for the observed occurrence pattern. We tested the following predictions: (1) increasing disturbance of the forested habitats affects the forest specialists; we hypothesised that the activity-density of the forest specialist carabid species should decrease from the less modified forested rural sites to the more altered urban ones; (2) there is no clear, unique activity-density pattern along the rural-urban gradient for the generalist species. It is controlled by numerous factors; the autecological characteristics of these species are in a complex interaction with the environmental variables and the urbanisation/disturbance level.

\section{Materials and methods}

\subsection{Study area and sampling methods}

Carabid beetles were studied along a rural-urban gradient in Debrecen, the second largest city of Hungary (Magura et al., 2004b). The rural, suburban and urban sampling areas were all part of a once-continuous forest (Nagyerdő Forest Reserve) bordering the city. All areas were situated in continuous patches of old (older than $100 \mathrm{yr}$ ) native Convallario-Quercetum forest association. The criteria for distinguishing sampling areas (rural, suburban, urban) were the ratio of the built-up area to the natural habitats measured by the ArcView GIS programme using an aerial photograph. In the rural area the built-up area was $0 \%$, in the suburban area it was approximately $30 \%$, while in the urban area the built-up area exceeded $60 \%$. In the urban area, several paths with asphalt surfaces had been created and the shrub layer was strongly thinned resulting in a park character, while in the suburban area the fallen trees were removed.

Distance between the sampling areas was at least $1 \mathrm{~km}$. Four sites, at least $50 \mathrm{~m}$ from each other (in order to achieve independency, see Digweed et al., 1995), were selected within each sampling area. Carabid beetles were collected at each of them using pitfall traps, randomly placing ten traps at least $10 \mathrm{~m}$ apart from each other at each site. This resulted in a total of 120 traps scattered along the rural-urban gradient $(3$ area $\times 4$ sites $\times 10$ traps). Each pitfall trap was at least $50 \mathrm{~m}$ from the nearest forest edge, in order to avoid edge effects (Molnár et al., 2001). The pitfall traps were unbaited, consisting of plastic cups (diameter $65 \mathrm{~mm}$, volume $250 \mathrm{ml}$ ) containing $75 \%$ ethylene glycol as a killing-preserving solution. The traps were covered with bark pieces to protect them from litter and rain (Spence and Niemelä, 1994). Trapped beetles were collected fortnightly from the end of March to the end of November, 2001. For analysis we pooled samples from the 8 month period.

Eight environmental factors were measured that can affect the distribution of carabids (Thiele, 1977; Lövei and Sunderland, 1996). Ground temperature at $2 \mathrm{~cm}$ depth, air temperature on the soil surface and relative humidity on the soil surface were measured in each site monthly on the morning of a typical sunny day. The statistical analyses were based on the averages of the monthly measures for the 12 sites. We also estimated the percentage cover of leaf litter, decaying wood material, herbs and shrubs in each site within a $10 \mathrm{~m} \times 10 \mathrm{~m}$ quadrat. We also counted the number of other invertebrates (other Coleoptera, Chilopoda, Diplopoda, Gastropoda, and Isopoda) in each trap of the sites as a measure of the amount of potential prey for carabids (Sergeeva, 1994). For analysis we pooled the amount of preys in the 12 sites for the whole year.

\subsection{Data analyses}

To test differences in the activity-density of the frequent species (which made up at least $1 \%$ of the total catch) among the three sampling areas (urban, suburban and rural), and among the 12 sites, nested analyses of variance (ANOVA) were performed using data from the individual traps (sites nested within the sampling areas). Habitat preference (forest, generalist and open-habitat species) of the frequent carabids was determined based in literature (Hůrka, 1996) in order to test predictions formulated above. Normal distribution of the data was achieved by $\log (x+1)$ transformation (Sokal and Rohlf, 1995). When ANOVA revealed a significant difference between the means, the Tukey test was performed for multiple comparisons among means.

The relationships between the environmental measurements and the activity-density of the frequent species were examined using the detrended canonical correspondence analysis by second order polynomials (DCCA) calculated by the CANOCO package (Ter Braak, 1986; Ter Braak and Šmilauer, 1998). Biplot scaling in the ordination was symmetric (focusing both on the inter-species and inter-samples distances), and the number of carabid individuals was $\log (x+1)$ transformed.

\section{Results}

The total carabid catch consisted of 2140 individuals representing 50 species. The number of individuals of 12 species each exceeded $1 \%$ of the total catch. For further data on the collected assemblages, see Magura et al. (2004b).

Of the frequent species, three species could be identified as forest specialist species (Amara saphyrea, Carabus convexus, 
Pterostichus oblongopunctatus), seven as generalist species (Amara convexior, Harpalus luteicornis, Notiophilus rufipes, Ophonus nitidulus, Pterostichus melanarius, Pterostichus niger, Stomis pumicatus) and two as open-habitat species (Anisodactylus nemorivagus, Bembidion lampros). The forest specialist $C$. convexus disappeared completely from the urban area. From the rural area the generalist $P$. melanarius was missing. In the suburban area the open-habitat species B. lampros was not caught. The open-habitat species A. nemorivagus was present only in the urban area.
All the three forest specialist species were more abundant in the rural and suburban areas than in the urban one. This difference was not statistically significant for $A$. saphyrea (Table 1 and Fig. 1). Of the seven generalist species, only two species showed significant variation in activity-density along the urbanisation gradient (Table 1). A. convexior was significantly more abundant in the urban sites, while $O$. nitidulus was significantly more numerous in the rural sites (Table 1 and Fig. 1). The other five generalist species were non-significantly more frequent either in the urban sites ( $N$. rufipes, P. melanarius), in the suburban sites

Table 1

Nested ANOVA showing differences in activity-density ( $\log x+1$ transformed) of the twelve frequent carabid species along the rural-suburban-urban gradient and among the 12 sites

\begin{tabular}{|c|c|c|c|c|c|c|}
\hline Species & Source of variation & d.f. & MS & $F$ & $p$ & Tukey test \\
\hline \multicolumn{7}{|l|}{ Forest specialist species } \\
\hline \multirow[t]{3}{*}{ Amara saphyrea } & Areas & 2 & 0.1143 & 2.5858 & $\mathrm{~ns}$ & \\
\hline & Sites & 9 & 0.0442 & 1.7164 & ns & \\
\hline & Error & 108 & 0.0258 & & & \\
\hline \multirow[t]{3}{*}{ Carabus convexus } & Areas & 2 & 0.7496 & 8.1775 & $<0.05$ & $U<S=R$ \\
\hline & Sites & 9 & 0.0917 & 2.1833 & $<0.05$ & \\
\hline & Error & 108 & 0.0420 & & & \\
\hline \multirow[t]{3}{*}{ Pterostichus oblongopunctatus } & Areas & 2 & 9.4888 & 12.1881 & $<0.01$ & $U<S<R$ \\
\hline & Sites & 9 & 0.7785 & 6.5148 & $<0.001$ & \\
\hline & Error & 108 & 0.1195 & & & \\
\hline \multicolumn{7}{|l|}{ Generalist species } \\
\hline \multirow[t]{3}{*}{ Amara convexior } & Areas & 2 & 0.4526 & 4.3899 & $<0.05$ & $U>S=R$ \\
\hline & Sites & 9 & 0.1031 & 2.7165 & $<0.01$ & \\
\hline & Error & 108 & 0.0380 & & & \\
\hline \multirow[t]{3}{*}{ Harpalus luteicornis } & Areas & 2 & 0.1225 & 2.6590 & ns & \\
\hline & Sites & 9 & 0.0461 & 2.8056 & $<0.01$ & \\
\hline & Error & 108 & 0.0164 & & & \\
\hline \multirow[t]{3}{*}{ Notiophilus rufipes } & Areas & 2 & 0.1870 & 2.5584 & ns & \\
\hline & Sites & 9 & 0.0731 & 2.9678 & $<0.01$ & \\
\hline & Error & 108 & 0.0246 & & & \\
\hline \multirow[t]{3}{*}{ Ophonus nitidulus } & Areas & 2 & 0.3681 & 4.5458 & $<0.05$ & $U=S<R$ \\
\hline & Sites & 9 & 0.0810 & 4.8581 & $<0.001$ & \\
\hline & Error & 108 & 0.0167 & & & \\
\hline \multirow[t]{3}{*}{ Pterostichus melanarius } & Areas & 2 & 0.2191 & 1.1006 & ns & \\
\hline & Sites & 9 & 0.1990 & 18.0396 & $<0.001$ & \\
\hline & Error & 108 & 0.0110 & & & \\
\hline \multirow[t]{3}{*}{ Pterostichus niger } & Areas & 2 & 0.0761 & 1.3449 & $\mathrm{~ns}$ & \\
\hline & Sites & 9 & 0.0566 & 3.2159 & $<0.01$ & \\
\hline & Error & 108 & 0.0176 & & & \\
\hline \multirow[t]{3}{*}{ Stomis pumicatus } & Areas & 2 & 0.1556 & 4.0765 & $\mathrm{~ns}$ & \\
\hline & Sites & 9 & 0.0382 & 2.0288 & $<0.05$ & \\
\hline & Error & 108 & 0.0188 & & & \\
\hline \multicolumn{7}{|l|}{ Open-habitat species } \\
\hline \multirow[t]{3}{*}{ Anisodactylus nemorivagus } & Areas & 2 & 0.2096 & 2.4459 & $\mathrm{~ns}$ & \\
\hline & Sites & 9 & 0.0857 & 6.0052 & $<0.001$ & \\
\hline & Error & 108 & 0.0143 & & & \\
\hline \multirow[t]{3}{*}{ Bembidion lampros } & Areas & 2 & 0.2038 & 1.8688 & & \\
\hline & Sites & 9 & 0.1090 & 6.2397 & $<0.001$ & \\
\hline & Error & 108 & 0.0175 & & & \\
\hline
\end{tabular}

Results of the Tukey test indicate which area(s) differ(s) significantly $(p<0.05)$ from the others; for example $U=S<R$ indicates that the activity-density of the given species was significantly higher in the rural area than in the urban and suburban areas (these two areas, however, were not different).

Please cite this article in press as: Magura, T., et al., A species-level comparison of occurrence patterns in carabids along an urbanisation gradient, Landscape Urban Plann (2008), doi:10.1016/j.landurbplan.2008.01.005 

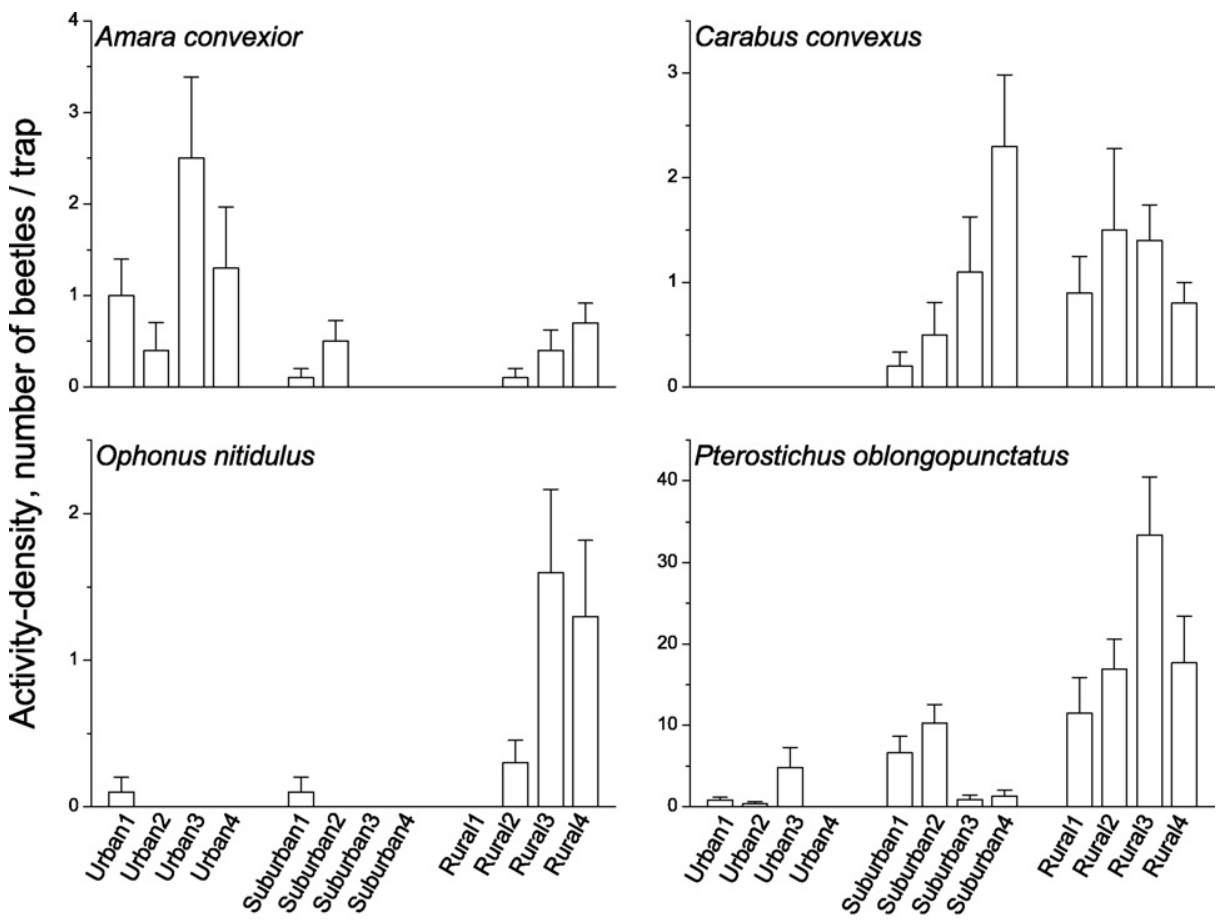

\section{Sampling sites}

Fig. 1. Average number of individuals $( \pm$ S.E.) of the species that showed significant variation in activity-density along the studied urbanisation gradient. Carabus convexus and Pterostichus oblongopunctatus are forest specialist species, while Amara convexior and Ophonus nitidulus are generalist species.

(H. luteicornis), in the rural sites (P. niger) or in the suburban and rural sites (S. pumicatus) (Table 1). The open-habitat species (A. nemorivagus, $B$. lampros) were more abundant in the urban sites, albeit the differences were statistically not significant (Table 1 ).

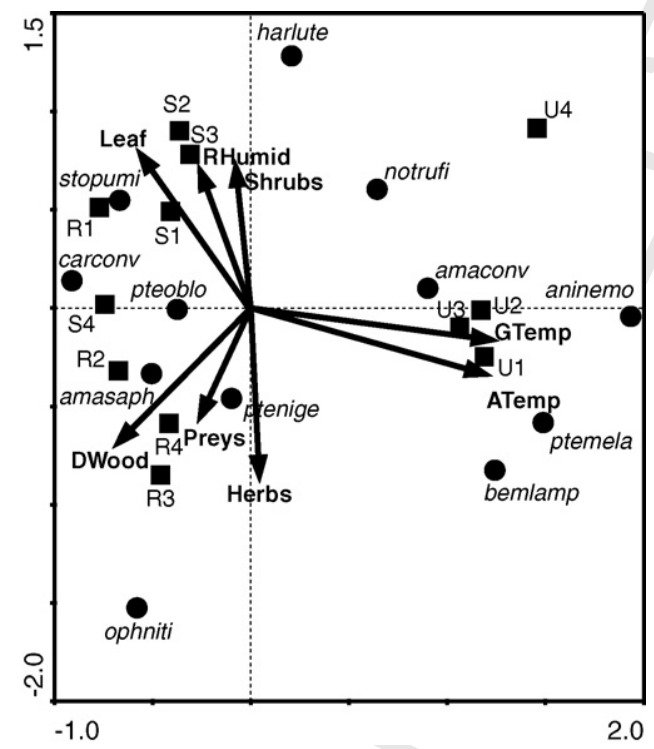

Fig. 2. DCCA for the twelve frequent carabid species which activity-density made up at least $1 \%$ of the total catch and for the 12 sites. Filled squares represent the studied sites (U1-U4: urban sites, S1-S4: suburban sites, and R1-R4: rural sites). The arrows denote the increase of the value of the studied environmental factors (GTemp: ground temperature at $2 \mathrm{~cm}$ depth; ATemp: air temperature on the surface; RHumid: relative humidity on the surface; Leaf: cover of leaf litter; DWood: cover of decaying wood material; Herbs: cover of herbs; and Shrubs: cover of shrubs). Filled circles and the seven-letter abbreviations indicate the species (e.g. amaconv: Amara convexior).
A triplot graph of the DCCA showed that there was a marked separation among the sites along the rural-urban gradient based on the activity-density of the twelve frequent species. The four urban sites differed from the suburban and rural sites which were more similar to each other (Fig. 2). Furthermore, the urban sites were characterised by higher ground and air temperatures. The suburban sites had a higher relative humidity and cover of leaf litter and shrubs, and the rural sites had higher amounts of decaying wood material, herbs and preys (Fig. 2). The triplot graph also demonstrated, that four species (A. convexior, A. nemorivagus, B. lampros, P. melanarius) were associated with the urban sites of higher ground and air temperature, while $N$. rufipes was intermediate between urban and suburban sites. Two species $(C$. convexus and P. oblongopunctatus) favoured the moderate or less disturbed suburban and rural sites, while S. pumicatus preferred the suburban sites (Fig. 2). Three species (A. saphyrea, $O$. nitidulus, $P$. niger) were characteristic of the rural sites with higher amounts of decaying wood, more herbs and prey items, while $H$. luteicornis was associated with the suburban sites with high shrub cover (Fig. 2).

\section{Discussion}

Our results showed that only four species $(C$. convexus, $P$. oblongopunctatus, A. convexior, and $O$. nitidulus) of the twelve frequent species responded significantly to the urbanisation. However, non-significant changes at the species level could accumulate and may have caused significant alterations at the community level. The multivariate analysis in this study showed that urban sites differed from the suburban and rural sites. The 
suburban and rural sites were quite similar to each other. These results are coherent with other studies which emphasised that urbanisation caused a pronounced change of carabid assemblages (Alaruikka et al., 2002; Niemelä et al., 2002; Ishitani et al., 2003; Venn et al., 2003; Magura et al., 2004b, 2005b; Weller and Ganzhorn, 2004; Gaublomme et al., 2005; Tóthmérész and Magura, 2005).

Two of the three forest specialist species, $C$. convexus and $P$. oblongopunctatus, responded significantly to urbanisation, as they occurred in lower number in the heavily disturbed urban sites than in the moderately or slightly disturbed suburban and rural sites. Other studies conducted in the frame of the Globenet programme confirmed our results, as they also showed that the overall number of individuals of the forest specialist species is significantly lower in the urban sites than in the suburban and rural sites (Magura et al., 2004b, 2005b; Gaublomme et al., 2005; Tóthmérész and Magura, 2005).

In our study, the activity-density of $C$. convexus and $P$. oblongopunctatus decreased as ground temperature and air temperature on the surface increased. These species are xerophilic and prefer sites with higher temperature (Thiele, 1977; Turin et al., 2003). These forest specialist species may be more sensitive to the habitat alteration rather than to changes in temperature. Ground and air temperature were higher in the urban habitats (heat island effect; Hawkins et al., 2004), but the higher temperature was accompanied with considerable habitat structure alterations. Consequently, these forest specialist species avoided these habitats. Sampling woodlots in the city centre of Hamburg and its rural borders, Weller and Ganzhorn (2004) also demonstrated that $P$. oblongopunctatus was more numerous in the suburban and rural sites than in the urban ones. Similar result was published by Gaublomme et al. (2005) studying forest patches in and around Brussels.

In our study the third most frequent forest specialist species, A. saphyrea, showed preference for the rural sites. Moreover, numbers increased with increasing amount of decaying wood materials. In Hungary, this species favours moist forests (Szél, 1996). As decaying wood material offers microsites with favourable humidity conditions, the positive relationship between the activity-density of the A. saphyrea and the amount of decaying wood materials is reasonable.

Of the generalist and open-habitat species, only A. convexior was significantly more numerous in the urban sites, as expected. Other three species (A. nemorivagus, B. lampros, $P$. melanarius) also occurred in higher number in the urban sites. All these species are related to the urban sites with higher ground and air temperature. The linking to these sites could be explained by their preference for microsites with higher temperature and/or by rapid colonisation of the new microsites established by urban disturbances (thinning, creating of paths). A. convexior, A. nemorivagus and B. lampros are xerophilic species (Thiele, 1977; Lindroth, 1985; Szél, 1996), while $P$. melanarius is eurythermic (Thiele, 1977) but macropterous (Hůrka, 1996). Therefore, it is a good coloniser of newly created microsites. Grandchamp et al. (2000) also showed that P. melanarius was strongly dominant in the heavily disturbed (trampled) sites.
The generalist $O$. nitidulus was numerous in the rural sites. Furthermore, its activity-density increased with the increasing amount of decaying wood, herbs and prey items. As this species is partially phytophagous (Larochelle, 1990) and occurs in slightly shaded habitats such as light deciduous forests (Lindroth, 1985), its association with the above habitat factors is logical.

The generalist species, $P$. niger, preferred the rural sites. The amount of decaying wood material, herbs and prey items were positively related to its activity-density. $P$. niger is a generalist predator and scavenger (Larochelle, 1990). Thus, the positive relationship between its activity-density and the amount of prey items is to be expected. Moreover, an increased herb cover can also increase the amount of invertebrate prey available for predatory carabids and can provide a more uniform resource distribution in time (Niemelä and Spence, 1994; Niemelä et al., 1994, 1996). This species is hygrophilic (Thiele, 1977) and prefers wet habitats (Szél, 1996). Decaying wood may provide favourable microsites with higher humidity, shelter against predators, and sites for aestivation, hibernation, egg and larval development (Thiele, 1977). Weller and Ganzhorn (2004) also showed that $P$. niger occurred exclusively in the rural sites.

The activity-density of $S$. pumicatus increased with relative humidity, cover of leaf litter and decreased with ground and air temperature. These relationships are expected, because this species is eurythermic and hygrophilic (Thiele, 1977). Several studies emphasised that more leaf litter may provide moister microclimate and better protection against environmental extremes (Koivula et al., 1999; Magura et al., 2004a, 2005a; Taboada et al., 2004).

This species-level study found that one third of the frequent species showed significant changes along the rural-urban gradient, while in the case of the other species only trends were recognisable. Therefore, we propose that the widespread practice of drastic alteration of habitat structure in parks (by strong thinning and removing decaying wood material) and creating only asphalt-covered paths should be avoided (Magura et al., 2004b). These practices are accompanied by unfavourable changes in the microclimatic, abiotic and biotic conditions that have a direct harmful effect on the forest specialist carabid species. Moreover, creating sealed paths has indirect effects through habitat loss, fragmentation and isolation (Didham et al., 1996). Reduction in the habitat area, fragmentation and isolation cause considerable changes in the composition of carabid assemblages (Davies and Margules, 1998). Therefore, there is a growing need for appropriate management strategies which simultaneously consider recreational, economic and conservation criteria (Gilbert, 1989). Habitat management which minimises the modification of habitat structure and tries to mimic natural processes could serve both the demands of citydwellers and the maintenance of biodiversity.

\section{Uncited reference}

Gibb and Hochuli (2002). 


\section{Acknowledgements}

The research was supported by the Hortobágy National Park Directorate and by the grant of the Hungarian Scientific Research Fund (OTKA research grant no. F61651). T.M. was Bolyai Research Fellow of the Hungarian Academy of Sciences.

\section{References}

Alaruikka, D.M., Kotze, D.J., Matveinen, K., Niemelä, J., 2002. Carabid and spider assemblages along an urban to rural gradient in Southern Finland. J. Insect Conserv. 6, 195-206.

Davies, K.F., Margules, C.R., 1998. Effects of habitat fragmentation on carabid beetles: experimental evidence. J. Anim. Ecol. 67, 460-471.

Didham, R.K., Ghazoul, J., Stork, N.E., Davis, A.J., 1996. Insects in fragmented forests: a functional approach. Tree 11, 255-260.

Digweed, S.C., Currie, C.R., Cárcamo, H.A., Spence, J.R., 1995. Digging out the digging-in effect of pitfall traps: influences of depletion and disturbance on catches of ground beetles (Coleoptera: Carabidae). Pedobiologia 39, 561-576.

Elek, Z., Lövei, G., 2005. Ground beetle (Coleoptera, Carabidae) assemblages along an urbanisation gradient near Sorø, Zealand, Denmark. Ent. Meddr. $73,115-121$.

Elek, Z., Lövei, G., 2007. Patterns in ground beetle (Coleoptera: Carabidae) assemblages along an urbanisation gradient in Denmark. Acta Oecol. 32, 104-111.

Gaublomme, E., Dhuyvetter, H., Verdyck, P., Desender, K., 2005. Effects of urbanisation on carabid beetles in old beech forests. In: Lövei, G.L., Toft, S. (Eds.), European Carabidology 2003. Proceedings of the 11th European Carabidologists' Meeting. DIAS Report. Flakkebjerg, pp. 111-123.

Gibb, H., Hochuli, D.F., 2002. Habitat fragmentation in an urban environment: large and small fragments support different arthropod assemblages. Biol. Conserv. 106, 91-100.

Gibbs, J.P., Stanton, E.J., 2001. Habitat fragmentation and arthropod community change: carrion beetles, phoretic mites, and flies. Ecol. Appl. 11, 79-85.

Gilbert, O.L., 1989. The Ecology of Urban Habitats. Chapman and Hall, London.

Godefroid, S., Koedam, N., 2003. Distribution pattern of the flora in a periurban forest: an effect of the city-forest ecotone. Landscape Urban Plan 65, 169-185.

Grandchamp, A.-C., Niemelä, J., Kotze, J., 2000. The effects of trampling on assemblages of ground beetles (Coleoptera, Carabidae) in urban forests in Helsinki, Finland. Urban Ecosyst. 4, 321-332.

Hawkins, T.W., Brazel, A.J., Stefanov, W.L., Bigler, W., Saffell, E.M., 2004. The role of rural variability in urban heat island determination for Phoenix, Arizona. J. Appl. Meteorol. 43, 476-486.

Hůrka, K., 1996. Carabidae of the Czech and Slovak Republics. Kabourek, Zlin. Ishitani, M., Kotze, D.J., Niemelä, J., 2003. Changes in carabid beetle assemblages across an urban-rural gradient in Japan. Ecography 26, 481-489.

Koivula, M., Punttila, P., Niemelä, J., 1999. Leaf litter and the small-scale distribution of carabid beetles (Coleoptera, Carabidae) in the boreal forest. Ecography 22, 424-435.

Larochelle, A., 1990. The food of carabid beetles. Fabr. Suppl. 5, 1-132.

Lindroth, C.H., 1985-86. The Carabidae (Coleoptera) of Fennoscandia and Denmark. Fauna Entomologica Skandinavica, Leiden and Copenhagen.

Lövei, G.L., Sunderland, K.D., 1996. Ecology and behavior of ground beetles (Coleoptera: Carabidae). Annu. Rev. Entomol. 41, 231-256.

Magura, T., Tóthmérész, B., Elek, Z., 2004a. Effects of leaf-litter addition on carabid beetles in a non-native norway spruce plantation. Acta Zool. Acad. Sci. Hung. 50, 9-23.

Magura, T., Tóthmérész, B., Elek, Z., 2005a. Impacts of leaf-litter addition on carabids in a conifer plantation. Biodivers. Conserv. 14, 475-491.

Magura, T., Tóthmérész, B., Molnár, T., 2004b. Changes in carabid beetle assemblages along an urbanisation gradient in the city of Debrecen, Hungary. Landscape Ecol. 19, 747-759.

Magura, T., Tóthmérész, B., Molnár, T., 2005b. Species richness of carabids along a forested urban-rural gradient in eastern Hungary. In: Lövei, G.L.,
Toft, S. (Eds.), European Carabidology 2003. Proceedings of the 11th European Carabidologists' Meeting. DIAS Report. Flakkebjerg, pp. 209-217.

McDonnell, M.J., Pickett, S.T.A., Groffman, P., Bohlen, P., Pouyat, R.V., Zipperer, W.C., Parmelee, R.W., Carreiro, M.M., Medley, K., 1997. Ecosystem processes along an urban-to-rural gradient. Urban Ecosyst. 1, 21-36.

McIntyre, N.E., 2000. Ecology of urban arthropods: a review and a call to action. Ann. Entomol. Soc. Am. 93, 825-835.

Molnár, T., Magura, T., Tóthmérész, B., 2001. Ground beetles (Carabidae) and edge effect in oak-hornbeam forest and grassland transects. Eur. J. Soil Biol. 37, 297-300.

Niemelä, J., Kotze, D.J., 2000. GLOBENET: the search for common anthropogenic impacts on biodiversity using carabids. In: Brandmayr, P., Lövei, G.L., Brandmayr, T.Z., Casale, A., Taglianti, A.V. (Eds.), Natural History and Applied Ecology of Carabid Beetles. Pensoft, Sofia-Moscow, pp. 241-246.

Niemelä, J., Spence, J.R., 1994. Distribution of forest dwelling carabids (Coleoptera): spatial scale and the concept of communities. Ecography 17, $166-175$.

Niemelä, J., Haila, Y., Punttila, P., 1996. The importance of small-scale heterogeneity in boreal forests: variation in diversity in forest-floor invertebrates across the succession gradient. Ecography 19, 352-368.

Niemelä, J., Kotze, J., Ashworth, A., Brandmayr, P., Desender, K., New, T., Penev, L., Samways, M., Spence, J., 2000. The search for common anthropogenic impacts on biodiversity: a global network. J. Insect Conserv. 4 , 3-9.

Niemelä, J., Kotze, J.D., Venn, S., Penev, L., Stoyanov, I., Spence, J., Hartley, D., Montes de Oca, E., 2002. Carabid beetle assemblages (Coleoptera, Carabidae) across urban-rural gradients: an international comparison. Landscape Ecol. 17, 387-401.

Niemelä, J., Spence, J.R., Langor, D., Haila, Y., Tukia, H., 1994. Logging and boreal ground-beetle assemblages on two continents: implications for conservation. In: Gaston, K., Samways, M., New, T. (Eds.), Perspectives in Insect Conservation. Intercept Publications, Andover, pp. 29-50.

Pouyat, R., Groffman, P., Yesilonis, I., Hernandez, L., 2002. Soil carbon pools and fluxes in urban ecosystems. Environ. Pollut. 116, 107-118.

Pouyat, R.V., McDonnell, M.J., Pickett, S.T.A., 1995. Soil characteristics of oak stands along an urban-rural land-use gradient. J. Environ. Qual. 24, 516-526.

Rainio, J., Niemelä, J., 2003. Ground beetles (Coleoptera: Carabidae) as bioindicators. Biodivers. Conserv. 12, 489-506.

Sadler, J.P., Small, E.C., Fiszpan, H., Telfer, M.G., Niemelä, J., 2006. Investigating environmental variation and landscape characteristics of an urban-rural gradient using woodland carabid assemblages. J. Biogeogr. 33, 1126-1138.

Sergeeva, T.K., 1994. Seasonal dynamics of interspecific trophic relations in a carabid beetle assemblage. In: Desender, K., Dufrêne, M., Loreau, M., Luff, M.L., Maelfait, J.-P. (Eds.), Carabid Beetles: Ecology and Evolution. Kluwer Academic Publishers, Dordrecht, pp. 367-370.

Sokal, R.R., Rohlf, F.J., 1995. Biometry. Freeman, New York.

Spence, J.R., Niemelä, J., 1994. Sampling carabid assemblages with pitfall traps: the madness and the method. Can. Entomol. 126, 881-894.

Szél, Gy., 1996. Rhysodidae, Cicindelidae \& Carabidae (Coleoptera) from the Bükk National Park. In: Mahunka, S., Zombori, L., Ádám, L. (Eds.), The Fauna of the Bükk National Park, II. Hungarian Natural History Museum, Budapest, pp. 159-222.

Taboada, A., Kotze, J., Salgado, M., 2004. Carabid beetle occurrence at the edges of oak and beech forests in NW Spain. Eur. J. Entomol. 101, 555-563.

Thiele, H.U., 1977. Carabid Beetles in Their Environments. Springer, New York.

Ter Braak, C.J.F., 1986. Canonical correspondence analysis: a new eigenvector method for multivariate direct gradient analysis. Ecology 67, 1167-1179.

Ter Braak, C.J.F., Šmilauer, P., 1998. CANOCO Reference Manual and User's Guide to Canoco for Windows. Software for Canonical Community Ordination (version 4). Centre for Biometry Wageningen and Microcomputer Power, Wageningen and Ithaca.

Tóthmérész, B., Magura, T., 2005. Affinity indices for environmental assessment using carabids. In: Lövei, G.L., Toft, S. (Eds.), European Carabidology 2003. Proceedings of the 11th European Carabidologists' Meeting. DIAS Report. Flakkebjerg, pp. 345-352.

Turin, H., Penev, L., Casale, A., 2003. The genus Carabus L. in Europe. A synthesis. In: Fauna Europaea Evertebrata. Pensoft Publishers, Sofia-Moscow. 
United Nations, 2004. World Urbanization Prospects: The 2003 Revision. United Nations Department of Economic and Social Affairs, Population Division, New York.

Venn, S.J., Kotze, D.J., Niemelä, J., 2003. Urbanization effects on carabid diversity in boreal forests. Eur. J. Entomol. 100, 73-80.

Weifeng, L., Zhiyun, O., Xuesong, M., Xiaoke, W., 2006. Plant species composition in relation to green cover configuration and function of urban parks in Beijing, China. Ecol. Res. 21, 221-237.
Weller, B., Ganzhorn, J.U., 2004. Carabid beetle community composition, body size, and fluctuating asymmetry along an urban-rural gradient. Basic Appl. Ecol. 5, 193-201.

Zhu, W.X., Carreiro, M.M., 2004. Variations of soluble organic nitrogen and microbial nitrogen in deciduous forest soils along an urban-rural gradient. Soil Biol. Biochem. 36, 279-288.

Please cite this article in press as: Magura, T., et al., A species-level comparison of occurrence patterns in carabids along an urbanisation gradient, Landscape Urban Plann (2008), doi:10.1016/j.landurbplan.2008.01.005 